\title{
Variability in Levels of Heavy Metals in Water and Fish (Chrysichthys nigrodigitatus) tissues from Badagry Creek, Nigeria
}

\author{
E. K Ajani \\ Department of Aquaculture and Fisheries Management \\ Faculty of Agriculture and Forestry, University of Ibadan, Nigeria \\ E-mail: ekajani@yahoo.co.uk \\ K. J Balogun (Corresponding author) \\ Nigerian Institute for Oceanography and Marine Research \\ Victoria Island, P.M.B 12729, Lagos, Nigeria \\ Tel: 234-803-560-8195Ｅ-mail: kayjaybal@yahoo.com
}

Received: January 10, 2015 Accepted: February 2, 2015

doi:10.5296/jbls.v6i2.7602 URL: http://dx.doi.org/10.5296/jbls.v6i2.7602

\begin{abstract}
The occurrence of metals viz., lead $(\mathrm{Pb})$, zinc $(\mathrm{Zn})$, copper $(\mathrm{Cu})$, iron $(\mathrm{Fe})$, cadmium $(\mathrm{Cd})$ and chromium (Cr) in water and fish ( Chrysichthys nigrodigitatus) samples collected bi-monthly from nine stations (water) and 3 designated landing sites (fish) of Badagry creek were investigated using atomic absorption spectrophotometer (AAS) method. With an exception of cadmium, metals concentration was lower in the water samples and higher in the fish tissues, indicating a bioaccumulation tendency of fish. Concentration levels in water were found in decreasing order of magnitude $\mathrm{Cr}>\mathrm{Pb}>\mathrm{Fe}>\mathrm{Zn}>\mathrm{Cu}>\mathrm{Cd}$. However, metals investigated except $\mathrm{Cu}$ (highest concentration in the liver) had highest concentrations in the fish gills, which could be related to the uptake pathway. The relatively lower wet season $\mathrm{Cu}, \mathrm{Pb}, \mathrm{Cr}$ and $\mathrm{Cd}$ in water could be attributed to a dilution effect of rainfall. Although, presently the mean concentrations of all the heavy metals except $\mathrm{Pb}$ in this study were moderate and within the Federal Environmental Protection Agency (FEPA) permissible standard limit for aquatic life, the elevation of metal concentrations in this creek is inevitable under the prevailing conditions of increasing urbanization, industrialization and other forms of modernization in
\end{abstract}


Badagry and environs. Nevertheless, it is imperative to ensure regular monitoring of heavy metal loading in this creek and other water bodies with a view to safeguard public health.

Keywords: Chrysichthys nigrodigitatus, Heavy metals, Bioaccumulation, Atomic absorption spectrophotometer

\section{Introduction}

Many human activities (such as mining, sewage discharge, overuse of chemicals, industrial waste from ports and refineries etc.) have a negative impact on several biological processes and there is no doubt that these will continue to affect the functioning of highly productive coastal ecosystems

Water pollution by heavy metals as a result of human activities is causing serious ecological problems in many parts of the world. This situation is aggravated by the lack of natural elimination processes for metals. As a result, metals shift from one compartment within the aquatic environment to another, including the biota, often with detrimental effects. Marine animals including fish concentrate toxins in their tissues and over time the toxins can accumulate and eventually kill the animals (Bhattacharya et al., 1994). Furthermore, where sufficient accumulation of the metals in biota occurs through food chain transfer, there is also an increasing toxicological risk for humans. Toxicity levels depend on the type and form of metals, its biological role, and the type of organisms that are exposed to it (Akan et al., 2010). According to Adepoju-Bello and Alabi, (2005), heavy metals can cause serious health effects with varied symptoms depending on the nature and the quantity of the metal ingested.

The assessment of metal pollution is an important aspect of most water quality assessment programs. The Global Environment Monitoring System (GEMS) programme GEMS/WATER includes ten metals: $\mathrm{Al}, \mathrm{Cd}, \mathrm{Cr}, \mathrm{Cu}, \mathrm{Fe}, \mathrm{Hg}, \mathrm{Mn}, \mathrm{Ni}, \mathrm{Pb}, \mathrm{Zn}$. Arsenic and $\mathrm{Se}$ (which are not strictly metals) are also included. The United States Environmental Protection Agency (USEPA) considers eight trace elements as high priority: $\mathrm{As}, \mathrm{Cd}, \mathrm{Cu}, \mathrm{Cr}, \mathrm{Pb}, \mathrm{Hg}, \mathrm{Ni}$ and $\mathrm{Zn}$. Most other countries include the same metals in their priority lists.

Badagry creek is one of the coastal waters in the Barrier Lagoon complex, Nigeria. The creek is one of the most ecologically important lagoon systems in Nigeria. The fish population from Badagry creek exhibits relatively high diversity and species richness. According to Agboola et al. (2008), among notable and highly demanded fish species in the creek included Cat fish (Chrysichthys nigrodigitatus), Bonga (Ethmalosa fimbriata) and Tilapia (Tilapia zillii). Furthermore, good markets for fish have led to full exploitation of fish resources in Badagry creek. These fishes are frequently and largely eaten in Badagry and environs, so their toxic metal content should be of concern to human health. The present study was therefore, carried out in view of the paucity of information about heavy metals in the fish from this region. In this paper, the levels of $\mathrm{Pb}, \mathrm{Cd}, \mathrm{Cu}, \mathrm{Fe}, \mathrm{Zn}$ and $\mathrm{Cr}$ in water samples and in tissues of $\mathrm{Cat}$ fish (Chrysichthys nigrodigitatus) are reported. The results of this study will help in generating data needed for the assessment of toxic metal intake from this source.

\section{Materials and methods}




\section{$\triangle$ Macrothink}

\subsection{Study Sites}

Badagry Creek, Nigeria is located between longitude $2^{\circ} 42^{1}$ and $3^{\circ} 23^{1} \mathrm{E}$ and latitude $6^{\circ} 23^{1}$ and $6^{\circ} 28^{1} \mathrm{~N}$. It is part of the $260 \mathrm{~km}$-long lagoon system stretching from Cotonou in Republic of Benin to the Niger Delta, although centered in Lagos state. It is estimated to be more than 51 $\mathrm{km}$ from Lagos. The creek is fed mainly by River Ajara in the Republic of Benin and the Yewa River in Nigeria while it also links Ologe Lagoon. The creek is shallow with irregular topography. The average water depth of Badagry creek is about $3.5 \mathrm{~m}$ The Creek is approximately equidistant from the entrances of Lagos and Cotonou harbours. As a result, it is influenced by tides and floods from the Lagos Lagoon and Cotonou harbour through Lake Nokue and Lake Porto-Novo (Anyanwu and Ezenwa, 1988).

\subsection{Climate of the Creek}

The Badagry creek is exposed to two distinct seasons namely the wet and the dry. Rainy season lasts from May to October and dry season lasts from November to April. Although, the month of August falls into wet season, usually a sharp drop in rainfall (downpour) is experienced (August break). The rainfall of Badagry is largely influenced by the southwest trade winds from the Atlantic Ocean and the dust-laden northeast trade (dry) winds from the Sahara desert become dominant during the dry months producing hazy weather conditions.

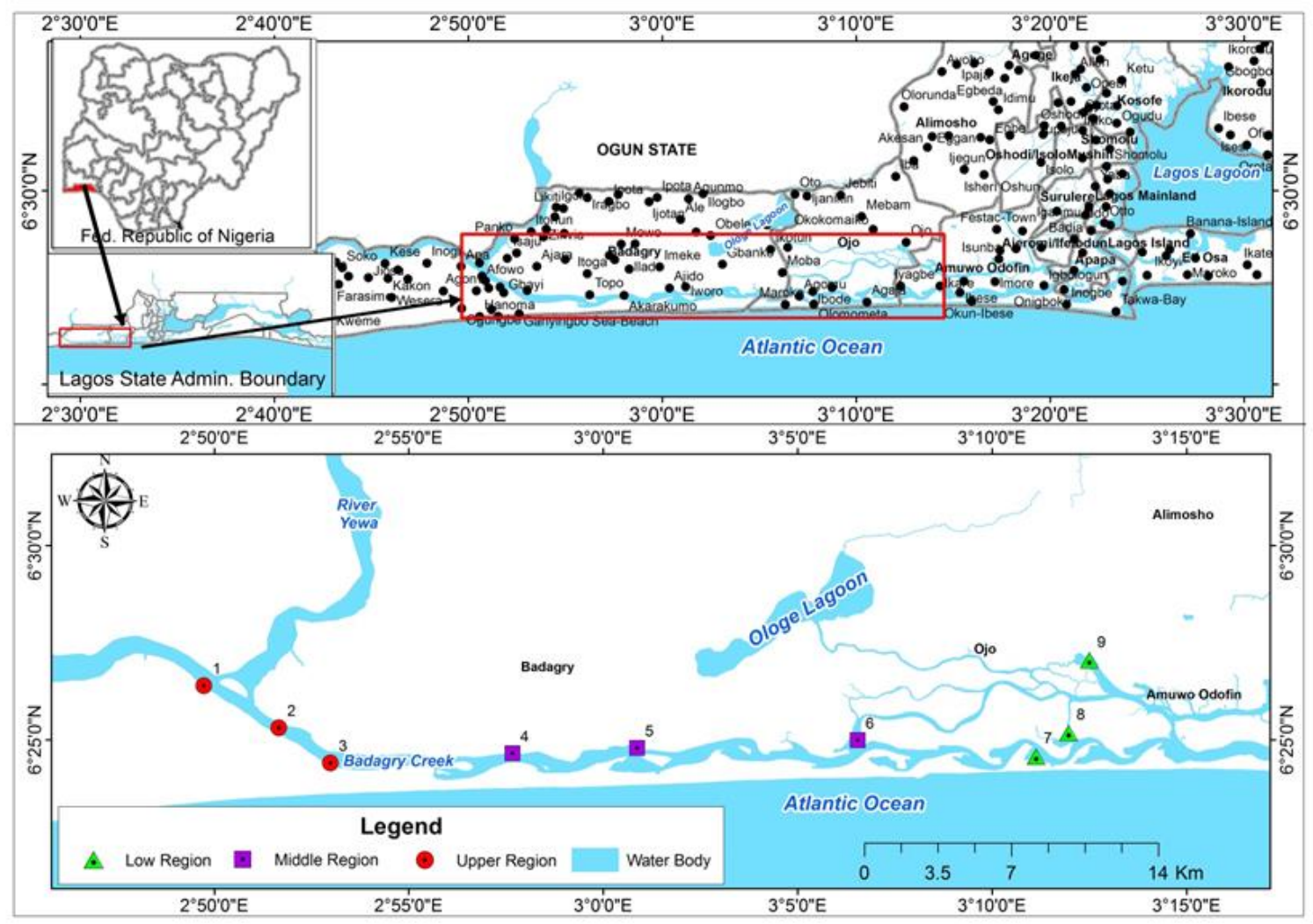

Figure 1. Map of Badagry Creek and environs with the sampling stations

1 - Apa; 2 - Igbaji; 3 - Yovovan jetty (Badagry*); 4 - Akarakumo; 5 - Ajido*; 6 - Irewe; 7 Igbolobi; 8 - Iyagbe; 9 - Ojo* 
*Selected Fishermen landing site in each of the zones for Fish collection

\subsection{Water and Fish Sampling}

The sampling strategies adopted for this study was stratified random sampling in which the creek was divided into three zones based on geographic locations and logistical characteristic: The upper, middle and lower zones (ISO, 2006). In each of the zones, three stations were randomly selected and chosen based on the major community settlement along the Badagry creek, thus giving a total of nine stations within the creek (Figure 1). The sampling was conducted between November 2011 and September 2013 covering 2 Dry and 2 Wet seasons. Water samples were taken bi-monthly throughout this period at the designated stations for analysis.

Water samples were collected just below the water surface at each station in acid-washed and pre-cleaned high density polyethylene (HDPE) bottles labelled according to the sampling station. $0.5 \mathrm{ml}$ concentrated $\mathrm{HNO}_{3}$ (reagent grade, Spectrosol, England) was added to each set of sample, and samples were transported to the Nigerian Institute for Oceanography and Marine Research central laboratory and refrigerated until analysis. The time lapse between sample collection, preservation and analysis was a week for each set of samples.

The fish species (Chrysichthys nigrodigitatus) were collected from the landings from fishermen at an established major fishing landing sites in each of the zones (Upper zone: Badagry; Middle zone: Ajido; Lower zone: Ojo). The fishes (six to eight average-sized specimens) were purchased from the fishermen who caught the fish at the designated zones. The fish were transported in a cooler containing ice to Nigerian Institute for Oceanography and Marine Research and refrigerated until dissection.

\subsubsection{Preparation and Digestion of Water Samples}

$25 \mathrm{ml}$ of preserved water samples were measured into a conical flask, $10 \mathrm{ml}$ of aqua regia (concentrated $\mathrm{HNO}_{3}$ ) was added. Thereafter the mixture was evaporated to $5 \mathrm{ml}$ on a hot plate in fume cupboard at $120^{\circ} \mathrm{C}$. The digested sample in the conical flask was allowed to cool and later filtered through Whatman filter paper no. 41 into $25 \mathrm{ml}$ volumetric flask and made up to the volume using de-ionize water. Then it was transferred to plastic vial waiting to be aspirated for metal analysis in an AAS and quantified against known standards (APHA, 1998).

\subsubsection{Preparation and Digestion of Fish Samples}

The preserved specimens (Chrysichthys nigrodigitatus) were thawed and wipe dry before laboratory analysis. All laboratory equipment for usage was cleaned with $\mathrm{HNO}_{3}$ prior to sample preparation. Fish were dissected with a dissecting set between the pectoral fin and vent of each fish. The muscle tissues of the finfishes were extracted. Likewise, the separated organs of the fishes (livers, gills, kidneys) were extracted.

The separated organs extracted were put in petri-dishes to dry at $120^{\circ} \mathrm{C}$ until reaching a constant weight. Thereafter, $2 \mathrm{~g}$ of separated organs were placed into digestion flasks and ultrapure Conc. $\mathrm{HNO}_{3}$ and $\mathrm{H}_{2} \mathrm{O}_{2}(2: 1 \mathrm{v} / \mathrm{v})$ was added. The samples were left overnight at 
room temperature. The digestion flasks containing the mixture were then heated to $130^{\circ} \mathrm{C}$ on a hot plate until dissolution and evaporated to $5 \mathrm{ml}$. After total digestion and subsequent cooling, the digested solution was filtered through Whatman filter paper no. 1 into $25 \mathrm{ml}$ volumetric flask (APHA, 1998). The reaction vessels and watch glasses were rinsed with distilled water to recover any residual metals inside $25 \mathrm{ml}$ volumetric flask and made up to the mark with de-ionize water.

\subsubsection{Determination of Element Concentrations}

Metal concentrations $(\mathrm{Pb}, \mathrm{Cr}, \mathrm{Cu}, \mathrm{Cd}, \mathrm{Zn}$ and $\mathrm{Fe}$ ) in the water and fish (Chrysichthys nigrodigitatus) specimen sampled for each set of samples were measured after samples had been digested using standard digestion procedure (APHA, 1998) with AAS by comparing their absorbance's with those of standards (solutions of known metal concentration) using an Alpha-4 cathode on AAS. For data quality, factory prepared AAS standard solutions were run as samples for accuracy check after every five measurements.

\subsection{Statistical Analyses}

The SPSS 15.0 for windows evaluation version was used to analyze the data obtained. Data were subjected to one way Analysis of variance (ANOVA) to examine differences with respect to sampling stations (zones) and seasons, a probability of $\mathrm{p}<0.05$ was considered significant. A post hoc Tukey Test was used to discern which means differed in concentration when there was a significant difference.

\section{Results}

\subsection{Levels of Metals in Water}

Iron varied from below the detection limit (BDL) to $5.87 \mathrm{mg} / \mathrm{l}$, with a grand mean of $1.87 \pm$ $0.52 \mathrm{mg} / \mathrm{l}$ (Table 2). The highest $(2.10 \pm 1.13 \mathrm{mg} / \mathrm{l})$ and lowest $(1.35 \pm 1.15 \mathrm{mg} / \mathrm{l}) \mathrm{mean} \mathrm{Fe}$ concentration were obtained at middle zone and lower zone, respectively (Table 1). Wet season average iron value of $2.10 \pm 1.35 \mathrm{mg} / \mathrm{l}$ was higher than $1.62 \pm 0.44 \mathrm{mg} / \mathrm{l}$ for dry season (Table 3). Results of ANOVA analysis showed significant differences in Fe values between seasons ( $\mathrm{p}<0.05)$. Copper ranged between below the detection limit (BDL) and $0.83 \mathrm{mg} / \mathrm{l}$, with the grand mean of $0.25 \pm 0.04 \mathrm{mg} / \mathrm{l}$ (Table 2). Mean $\mathrm{Cu}$ concentration varies slightly among zones, and was least $(0.21 \pm 0.18 \mathrm{mg} / \mathrm{l})$ at the lower zone and highest $(0.25 \pm$ $0.19 \mathrm{mgL}^{-1}$ ) at the middle zone (Table 1). Seasonal trend (Table 3) revealed dry season had higher copper mean $(0.28 \pm 0.25 \mathrm{mg} / \mathrm{l})$ than wet season $(0.18 \pm 0.12 \mathrm{mg} / \mathrm{l})$. Statistical analysis on the results revealed that $\mathrm{Cu}$ values between seasons differed significantly $(\mathrm{p}<0.05)$.

Lead levels varied from $0.17 \mathrm{mg} / \mathrm{l}$ to $19.18 \mathrm{mg} / \mathrm{l}$ throughout this study. The highest $(4.40 \pm$ $\left.3.03 \mathrm{mgL}^{-1}\right)$ and lowest $\left(2.58 \pm 2.63 \mathrm{mgL}^{-1}\right)$ mean $\mathrm{Pb}$ content was recorded at middle zone and lower zone respectively (Table 1). Seasonally (Table 3$)$, Pb value was higher $(3.89 \pm 3.73$ $\mathrm{mg} / \mathrm{l})$ in the dry season than in wet season $(2.89 \pm 1.58 \mathrm{mg} / \mathrm{l})$. However, ANOVA on the results showed no significant differences in $\mathrm{Pb}$ values between zones $(\mathrm{p}>0.05)$ and seasons $(\mathrm{p}>0.05)$.

Zinc ranged from below the detection limit to $4.25 \mathrm{mg} / \mathrm{l}$, with a grand mean of $0.28 \pm$ 


\section{$\Lambda$ Macrothink}

$0.38 \mathrm{mg} / \mathrm{l}$ (Table 2). $\mathrm{Zn}$ mean, (Table 1) increased slightly from the lower zone (0.18 \pm $0.05 \mathrm{mg} / \mathrm{l})$ to the upper zone $(1.29 \pm 1.33 \mathrm{mg} / \mathrm{l})$. However, wet season (Table 3$)$ mean $\mathrm{Zn}$ concentration $(0.84 \pm 0.83 \mathrm{mg} / \mathrm{l})$ was higher than the dry season of $0.52 \pm 0.57 \mathrm{mg} / \mathrm{l}$. Zn mean values differed significantly across zones $(\mathrm{p}<0.05)$, but the difference was not seasonally significant $(\mathrm{p}>0.05)$.

Chromium varied from $0.89 \mathrm{mg} / 1$ to $35.47 \mathrm{mg} / \mathrm{l}$ throughout the study. Mean Cr content (Table 1) increased from the upper zone $\left(8.28 \pm 4.35 \mathrm{mgL}^{-1}\right)$ in this study to the lower zone $(10.78 \pm$ $8.07 \mathrm{mgL}^{-1}$ ), with a grand average value of $9.82 \pm 2.60 \mathrm{mgL}^{-1}$ (Table 2). Season-wise (Table 3), the dry season $\mathrm{Cr}$ mean value $(10.70 \pm 7.27 \mathrm{mg} / \mathrm{l})$ was higher than the wet season value of $8.94 \pm 4.93 \mathrm{mg} / \mathrm{l}$. However, ANOVA showed there were no significant difference in Cr mean values between zones $(\mathrm{p}>0.05)$ and seasons $(\mathrm{p}>0.05)$.

Cadmium levels were generally very low and were between below the detection limit and $0.48 \mathrm{mg} / \mathrm{l}$. Mean Cd varies slightly among zones, with the lowest $(0.12 \pm 0.11 \mathrm{mg} / \mathrm{l})$ at upper zone and highest $(0.14 \pm 0.09 \mathrm{mg} / \mathrm{l})$ at middle zone (Table 1$)$. Cd grand mean in this study was $0.15 \pm 0.05 \mathrm{mg} / \mathrm{l}$ (Table 2). Seasonally (Table 3), Cd mean value in dry season $(0.16 \pm$ $\left.0.12 \mathrm{mgL}^{-1}\right)$ was higher than in the wet season $\left(0.11 \pm 0.06 \mathrm{mgL}^{-1}\right)$. However, between the sampling zones and seasons, the Cd concentrations did not differ significantly $(\mathrm{p}>0.05)$.

Considering the mean concentrations of the studied metals, the order of magnitudes (highest to lowest) was $\mathrm{Cr}>\mathrm{Pb}>\mathrm{Fe}>\mathrm{Zn}>\mathrm{Cu}>\mathrm{Cd}$.

Table 1. Spatial (Zone) variation (Means \pm standard deviation) of Metals in Badagry Creek water (November, 2011 - September, 2013)

\begin{tabular}{|l|l|l|l|l|}
\hline Parameters & UPPER ZONE & MIDDLE ZONE & LOWER ZONE & P value \\
\hline $\mathrm{Fe}(\mathrm{mg} / \mathrm{l})$ & $2.09 \pm 0.90 \mathrm{a}$ & $2.10 \pm 1.13 \mathrm{a}$ & $1.35 \pm 1.15 \mathrm{a}$ & $>0.05$ \\
\hline $\mathrm{Cu}(\mathrm{mg} / \mathrm{l})$ & $0.23 \pm 0.22 \mathrm{a}$ & $0.25 \pm 0.19 \mathrm{a}$ & $0.21 \pm 0.18 \mathrm{a}$ & $>0.05$ \\
\hline $\mathrm{Pb}(\mathrm{mg} / \mathrm{l})$ & $3.18 \pm 3.13 \mathrm{a}$ & $4.40 \pm 3.03 \mathrm{a}$ & $2.58 \pm 2.63 \mathrm{a}$ & $>0.05$ \\
\hline $\mathrm{Zn}(\mathrm{mg} / \mathrm{l})$ & $1.29 \pm 1.33 \mathrm{a}$ & $0.21 \pm 0.07 \mathrm{~b}$ & $0.18 \pm 0.05 \mathrm{~b}$ & $<0.05$ \\
\hline $\mathrm{Cr}(\mathrm{mg} / \mathrm{l})$ & $8.28 \pm 4.35 \mathrm{a}$ & $10.41 \pm 6.11 \mathrm{a}$ & $10.78 \pm 8.07 \mathrm{a}$ & $>0.05$ \\
\hline $\mathrm{Cd}(\mathrm{mg} / \mathrm{l})$ & $0.12 \pm 0.11 \mathrm{a}$ & $0.14 \pm 0.09 \mathrm{a}$ & $0.13 \pm 0.11 \mathrm{a}$ & $>0.05$ \\
\hline
\end{tabular}




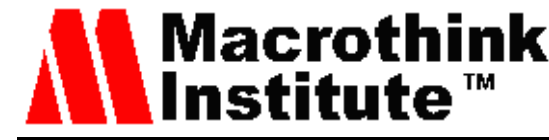

Table 2. Grand mean \pm standard deviation of Metals in Badagry Creek water (November, 2011 - September, 2013)

\begin{tabular}{|l|l|l|}
\hline Parameters & Mean $\pm \mathrm{SD}$ & FEPA 1991 (Aquatic life limit) \\
\hline $\mathrm{Fe}(\mathrm{mg} / \mathrm{l})$ & $1.87 \pm 0.52$ & 1.0 \\
\hline $\mathrm{Cu}(\mathrm{mg} / \mathrm{l})$ & $0.25 \pm 0.04$ & 1.0 \\
\hline $\mathrm{Pb}(\mathrm{mg} / \mathrm{l})$ & $3.39 \pm 1.35$ & $<1$ \\
\hline $\mathrm{Zn}(\mathrm{mg} / \mathrm{l})$ & $0.28 \pm 0.38$ & 5 \\
\hline $\mathrm{Cr}(\mathrm{mg} / \mathrm{l})$ & $9.82 \pm 2.60$ & 10 \\
\hline $\mathrm{Cd}(\mathrm{mg} / \mathrm{l})$ & $0.15 \pm 0.05$ & $<1$ \\
\hline
\end{tabular}

FEPA: Federal Environmental Protection Agency

Table 3. Seasonal Variation (Mean \pm Standard Deviation) of Metals in Badagry Creek water (November, 2011 - September, 2013).

\begin{tabular}{|l|l|l|l|}
\hline Parameters & Dry season & Wet season & P value \\
\hline $\mathrm{Fe}(\mathrm{mg} / \mathrm{l})$ & $1.62 \pm 0.44$ & $2.10 \pm 1.35$ & $<0.05$ \\
\hline $\mathrm{Cu}(\mathrm{mg} / \mathrm{l})$ & $0.28 \pm 0.25$ & $0.18 \pm 0.12$ & $<0.05$ \\
\hline $\mathrm{Pb}(\mathrm{mg} / \mathrm{l})$ & $3.89 \pm 3.73$ & $2.89 \pm 1.58$ & $>0.05$ \\
\hline $\mathrm{Zn}(\mathrm{mg} / \mathrm{l})$ & $0.52 \pm 0.57$ & $0.84 \pm 0.88$ & $>0.05$ \\
\hline $\mathrm{Cr}(\mathrm{mg} / \mathrm{l})$ & $10.71 \pm 7.27$ & $8.94 \pm 4.93$ & $>0.05$ \\
\hline $\mathrm{Cd}(\mathrm{mg} / \mathrm{l})$ & $0.16 \pm 0.12$ & $0.11 \pm 0.06$ & $>0.05$ \\
\hline
\end{tabular}

\subsection{Levels of Metals in Fish Species Tissues}

Metal concentrations in the muscle, liver, gill and kidney of the investigated fish species (Chrysichthys nigrodigitatus) from the three zones of Badagry creek are shown in Tables 4 6.

The values vary at different zones of the creek. Fe in the finfish muscles ranged from 15.14 to $187.32 \mathrm{mg} / \mathrm{kg}$. The lower zone had the highest mean Iron value $(73.74 \pm 56.77 \mathrm{mg} / \mathrm{kg})$ while upper zone recorded the lowest mean content $(29.44 \pm 8.75 \mathrm{mg} / \mathrm{kg})$. Detectable $\mathrm{Cu}$ content varied between $0.06 \mathrm{mg} / \mathrm{kg}$ and $1.49 \mathrm{mg} / \mathrm{kg}$ with a grand mean of $0.67 \pm 0.29 \mathrm{mg} / \mathrm{kg}$. The highest $(0.83 \pm 0.49 \mathrm{mg} / \mathrm{kg})$ and lowest $(0.46 \pm 0.49 \mathrm{mg} / \mathrm{kg}) \mathrm{Cu}$ mean concentration were obtained at the middle and lower zones respectively. $\mathrm{Pb}$ concentrations were from 7.09 to $25.76 \mathrm{mg} / \mathrm{kg}$. Lower zone with the highest Lead mean value $(18.38 \pm 5.21 \mathrm{mg} / \mathrm{kg})$ while the least mean content $(10.21 \pm 1.80 \mathrm{mg} / \mathrm{kg})$ was obtained at the upper zone. $\mathrm{Zn}$ levels varied from 10.55 to $26.52 \mathrm{mg} / \mathrm{kg}$ with a grand mean of $15.92 \pm 2.82 \mathrm{mg} / \mathrm{kg}$. The lowest $(13.08 \pm$ $2.36 \mathrm{mg} / \mathrm{kg})$ and highest $(19.29 \pm 4.36 \mathrm{mg} / \mathrm{kg}) \mathrm{Zn}$ average content were obtained at the upper and lower zones respectively. Cr content varied from $18.64 \mathrm{mg} / \mathrm{kg}$ to $229.34 \mathrm{mg} / \mathrm{kg}$, with highest $(156.11 \pm 44.68 \mathrm{mg} / \mathrm{kg})$ and lowest $(40.624 \pm 18.19 \mathrm{mg} / \mathrm{kg})$ mean concentration recorded at lower and upper zones respectively. Cd was below detection limit in the muscle of Chrysichthys nigrodigitatus. Metals in fish muscle with an exception of iron and lead revealed higher dry season mean values. Statistical analyses on metal concentration in the muscle except $\mathrm{Cu}$ showed significant differences between the zones $(\mathrm{p}<0.05)$. However, 
between the seasons, with an exception of $\mathrm{Cr}$, the concentrations did not differ significantly. The rank of mean metal concentration in the muscle tissues in decreasing order of magnitude was: $\mathrm{Cr}>\mathrm{Fe}>\mathrm{Zn}>\mathrm{Pb}>\mathrm{Cu}>\mathrm{Cd}$.

In the liver of Chrysichthys nigrodigitatus, Fe concentration ranged from 19.45 to $564.92 \mathrm{mg} / \mathrm{kg}$ with a grand mean of $174.51 \pm 56.58 \mathrm{mg} / \mathrm{kg}$. Fe mean content was highest at the upper zone $(337.89 \pm 115.14 \mathrm{mg} / \mathrm{kg})$ and lowest $(75.12 \pm 56.71 \mathrm{mg} / \mathrm{kg})$ at the middle zone. Upper zone had highest $\mathrm{Cu}$ mean $(3.89 \pm 4.08 \mathrm{mg} / \mathrm{kg})$ while the lowest mean $(1.40 \pm$ $1.91 \mathrm{mg} / \mathrm{kg}$ ) was recorded at the middle zone. $\mathrm{Pb}$ content in the fish liver was from 7.34 to $27.27 \mathrm{mg} / \mathrm{kg}$, with a grand $\mathrm{Pb}$ mean of $15.10 \pm 2.64 \mathrm{mg} / \mathrm{kg}$. Pb mean content was least at the upper zone $(10.73 \pm 2.01 \mathrm{mg} / \mathrm{kg})$ and highest $(19.55 \pm 4.56 \mathrm{mg} / \mathrm{kg})$ at the lower zone. $\mathrm{Zn}$ content varied between 3.52 and $25.74 \mathrm{mg} / \mathrm{kg}$. The highest $(17.49 \pm 5.48 \mathrm{mg} / \mathrm{kg})$ and lowest $(7.94 \pm 4.81 \mathrm{mg} / \mathrm{kg}) \mathrm{Zn}$ mean content were obtained at lower and middle zones respectively. Cr level ranged from 14.00 to $251.56 \mathrm{mg} / \mathrm{kg}$, with a grand mean of $103.29 \pm 30.81 \mathrm{mg} / \mathrm{kg}$. Cr mean value was highest at the lower zone $(153.26 \pm 65.81 \mathrm{mg} / \mathrm{kg})$ and lowest $(63.96 \pm$ $43.98 \mathrm{mg} / \mathrm{kg}$ ) at the upper zone. Cd was not detected in the liver of the finfish (Chrysichthys nigrodigitatus) investigated. With an exception of copper and $\mathrm{Cr}$, wet season metal mean concentrations were higher than dry season values. Metal concentrations (Cr exception) in the fish liver did not vary between the seasons. Between the sampling zones, with an exception of $\mathrm{Cu}$, the concentrations did not differ significantly. The metal ranking in finfish liver was $\mathrm{Fe}>\mathrm{Cr}>\mathrm{Pb}>\mathrm{Zn}>\mathrm{Cu}>\mathrm{Cd}$.

Concentration of $\mathrm{Fe}$ in Chrysichthys nigrodigitatus gills ranged from 60.42 to $342.57 \mathrm{mg} / \mathrm{kg}$. Fe mean values was highest $(241.62 \pm 55.35 \mathrm{mg} / \mathrm{kg})$ at the upper zone and least $(171.45 \pm$ $66.49 \mathrm{mg} / \mathrm{kg}$ ) at the lower zone. Cu varied between 0.14 and $5.98 \mathrm{mg} / \mathrm{kg}$, with a grand average of $1.64 \pm 0.92 \mathrm{mg} / \mathrm{kg}$. The highest $(2.67 \pm 1.96 \mathrm{mg} / \mathrm{kg})$ and the lowest $(0.64 \pm 0.28 \mathrm{mg} / \mathrm{kg}) \mathrm{Cu}$ mean content in gill were recorded at the upper and middle zones respectively. $\mathrm{Pb}$ fluctuated between 9.95 and $31.06 \mathrm{mg} / \mathrm{kg}$. Pb mean content was highest $(20.87 \pm 2.67 \mathrm{mg} / \mathrm{kg})$ at the middle zone and lowest $(12.79 \pm 1.97 \mathrm{mg} / \mathrm{kg})$ at the upper zone. Zn level was from 19.86 to $40.01 \mathrm{mg} / \mathrm{kg}$. Lower zone had the highest $\mathrm{Zn}$ mean value $(30.06 \pm 5.66 \mathrm{mg} / \mathrm{kg})$ while the least $(25.74 \pm 4.48 \mathrm{mg} / \mathrm{kg})$ was obtained at the middle zone. Cr content varied from 41.52 to $279.31 \mathrm{mg} / \mathrm{kg}$ with a grand average of $115.61 \pm 29.47 \mathrm{mg} / \mathrm{kg}$. The highest $\mathrm{Cr}$ mean value $(190.52 \pm 65.63 \mathrm{mg} / \mathrm{kg})$ and the lowest $(67.95 \pm 21.00 \mathrm{mg} / \mathrm{kg})$ were obtained at the lower and upper zones respectively. $\mathrm{Cd}$ in fish gill ranged from below the detection limit to $0.15 \mathrm{mg} / \mathrm{kg}$. The highest $(0.13 \pm 0.06 \mathrm{mg} / \mathrm{kg})$ and lowest $(0.10 \pm 0.04 \mathrm{mg} / \mathrm{kg}) \mathrm{Cd}$ mean values were obtained at the upper and middle zones respectively. With an exception of $\mathrm{Cd}$, metals dry season mean values were higher than the wet season. The ranking of metals concentration in gill was $\mathrm{Fe}>\mathrm{Cr}>\mathrm{Zn}>\mathrm{Pb}>\mathrm{Cu}>\mathrm{Cd}$. Metal concentrations with an exception of $\mathrm{Cu}$ and $\mathrm{Cr}$, in the fish gill did not vary between the seasons. However, between the sampling zones, metal concentration except $\mathrm{Cd}$ showed significant differences $(\mathrm{p}<0.05)$.

In fish kidney, Fe content ranged from 26.36 to $109.54 \mathrm{mg} / \mathrm{kg}$, with a grand mean of $66.66 \pm$ $11.94 \mathrm{mg} / \mathrm{kg}$. The highest and lowest Fe mean values were obtained at upper $(82.275 \pm 17.592)$ and lower zones $(58.077 \pm 23.320)$ respectively. Detectable $\mathrm{Cu}$ levels varied from 0.04 to $3.70 \mathrm{mg} / \mathrm{kg}$. Lower zone had the highest mean $\mathrm{Cu}$ concentration $(1.54 \pm 1.23 \mathrm{mg} / \mathrm{kg})$ while 


\section{Al Macrothink}

Journal of Biology and Life Science ISSN 2157-6076 2015, Vol. 6, No. 2

lowest $(0.11 \pm 0.09 \mathrm{mg} / \mathrm{kg})$ was obtained at upper zone. Pb fluctuated between 6.89 to $27.45 \mathrm{mg} / \mathrm{kg}$. Spatial trend showed lower and upper zones with the highest $(20.83 \pm$ $4.90 \mathrm{mg} / \mathrm{kg})$ and lowest $(10.15 \pm 2.00 \mathrm{mg} / \mathrm{kg}) \mathrm{Pb}$ mean concentration respectively. Zn content range was from 5.31 to $16.10 \mathrm{mg} / \mathrm{kg}$. Spatially, lower zone had the highest $\mathrm{Zn}$ average value $(11.89 \pm 3.03 \mathrm{mg} / \mathrm{kg})$ while the middle zone obtained the lowest mean of $7.81 \pm 1.37 \mathrm{mg} / \mathrm{kg}$. $\mathrm{Cr}$ varied from 17.52 to $273.77 \mathrm{mg} / \mathrm{kg}$ with a grand average of $86.30 \pm 22.15 \mathrm{mg} / \mathrm{kg}$. The lowest $(29.13 \pm 11.77 \mathrm{mg} / \mathrm{kg})$ and highest $(176.15 \pm 65.50 \mathrm{mg} / \mathrm{kg}) \mathrm{Cr}$ mean values were recorded at the upper and lower zones respectively. Cd content was from below detection limit to $0.13 \mathrm{mg} / \mathrm{kg}$ in the fish kidney. Cd levels were below detection limit in the fish kidney at both the upper and middle zones throughout the study. Generally, wet season metals mean contents in kidney with an exception of $\mathrm{Fe}$ and $\mathrm{Cr}$ were higher than the dry season mean values. Metal concentrations with an exception of $\mathrm{Cd}$ showed significant differences between the zones. However, $\mathrm{Fe}, \mathrm{Cu}$ and $\mathrm{Cd}$ did not differ between seasons ( $\mathrm{p}>0.05$ ). Metals concentration ranking in finfish kidney was $\mathrm{Cr}>\mathrm{Fe}>\mathrm{Pb}>\mathrm{Zn}>\mathrm{Cu}>\mathrm{Cd}$.

Table 4. Spatial distribution (Mean \pm standard deviation) of Heavy metal concentration in different tissues of (Chrysichthys nigrodigitatus) fish species from Badagry Creek (November, 2011 - September, 2013)

\begin{tabular}{|c|c|c|c|c|c|}
\hline Metals & Fish tissues & Upper Zone & Middle Zone & Lower Zone & $P$ value \\
\hline \multirow[t]{4}{*}{$\mathrm{Fe}(\mathrm{mg} / \mathrm{kg})$} & muscle & $29.44 \pm 8.75 b$ & $34.05 \pm 9.52 b$ & $73.74 \pm 56.77 \mathrm{a}$ & $<0.05$ \\
\hline & liver & $337.89 \pm 115.14 a$ & $75.11 \pm 56.71 \mathrm{c}$ & $110.52 \pm 58.58 b$ & $<0.05$ \\
\hline & gill & $241.62 \pm 55.35 \mathrm{a}$ & $205.63 \pm 46.13 b$ & $171.45 \pm 66.49 c$ & $<0.05$ \\
\hline & kidney & $82.27 \pm 17.59 \mathrm{a}$ & $59.64 \pm 11.98 b$ & $58.07 \pm 23.32 b$ & $<0.05$ \\
\hline \multirow[t]{4}{*}{$\mathrm{Cu}(\mathrm{mg} / \mathrm{kg})$} & muscle & $0.53 \pm 0.36 a$ & $0.82 \pm 0.49 a$ & $0.46 \pm 0.49 a$ & $>0.05$ \\
\hline & liver & $3.89 \pm 4.07 \mathrm{a}$ & $1.40 \pm 1.91 \mathrm{a}$ & $2.93 \pm 3.16 \mathrm{a}$ & $>0.05$ \\
\hline & gill & $2.67 \pm 1.96 \mathrm{a}$ & $0.64 \pm 0.28 c$ & $1.91 \pm 1.51 \mathrm{~b}$ & $<0.05$ \\
\hline & kidney & $0.11 \pm 0.09 b$ & $0.48 \pm 0.33 b$ & $1.54 \pm 1.23 \mathrm{a}$ & $<0.05$ \\
\hline \multirow[t]{4}{*}{$\mathrm{Pb}(\mathrm{mg} / \mathrm{kg})$} & muscle & $10.21 \pm 1.80 \mathrm{~b}$ & $16.74 \pm 3.11 \mathrm{ab}$ & $18.38 \pm 5.21 \mathrm{a}$ & $<0.05$ \\
\hline & liver & $10.73 \pm 2.01 \mathrm{~b}$ & $15.02 \pm 2.54 \mathrm{ab}$ & $19.55 \pm 4.56 \mathrm{a}$ & $<0.05$ \\
\hline & gill & $12.79 \pm 1.97 \mathrm{~b}$ & $20.87 \pm 2.67 \mathrm{a}$ & $20.51 \pm 5.88 \mathrm{a}$ & $<0.05$ \\
\hline & kidney & $10.15 \pm 2.00 \mathrm{~b}$ & $13.60 \pm 4.18 b$ & $20.83 \pm 4.90 \mathrm{a}$ & $<0.05$ \\
\hline \multirow[t]{4}{*}{$\mathrm{Zn}(\mathrm{mg} / \mathrm{kg})$} & muscle & $13.08 \pm 2.36 b$ & $15.39 \pm 2.75 b$ & $19.29 \pm 4.34 \mathrm{a}$ & $<0.05$ \\
\hline & liver & $15.97 \pm 5.72 \mathrm{a}$ & $7.94 \pm 4.81 b$ & $17.49 \pm 5.48 \mathrm{a}$ & $<0.05$ \\
\hline & gill & $28.61 \pm 4.65 \mathrm{ab}$ & $25.74 \pm 4.48 b$ & $30.06 \pm 5.66 \mathrm{a}$ & $<0.05$ \\
\hline & kidney & $7.84 \pm 2.19 b$ & $7.81 \pm 1.37 \mathrm{~b}$ & $11.89 \pm 3.03 \mathrm{a}$ & $<0.05$ \\
\hline \multirow[t]{3}{*}{$\mathrm{Cr}(\mathrm{mg} / \mathrm{kg})$} & muscle & $40.62 \pm 18.19 \mathrm{c}$ & $86.18 \pm 38.18 b$ & $156.11 \pm 44.68 \mathrm{a}$ & $<0.05$ \\
\hline & liver & $63.96 \pm 43.98 c$ & $92.65 \pm 51.27 \mathrm{~b}$ & $153.26 \pm 65.81 \mathrm{a}$ & $<0.05$ \\
\hline & gill & $67.95 \pm 21.00 \mathrm{~b}$ & $88.35 \pm 29.97 b$ & $190.52 \pm 65.63 \mathrm{a}$ & $<0.05$ \\
\hline
\end{tabular}




\begin{tabular}{|l|l|l|l|l|l|}
\hline \multirow{2}{*}{$\mathrm{Cd}(\mathrm{mg} / \mathrm{kg})$} & kidney & $29.13 \pm 11.77 \mathrm{c}$ & $53.61 \pm 13.58 \mathrm{~b}$ & $176.15 \pm 65.50 \mathrm{a}$ & $<0.05$ \\
\cline { 2 - 6 } & & & & & \\
\cline { 2 - 6 } & muscle & BDL & BDL & BDL & \\
\cline { 2 - 6 } & giver & BDL & BDL & BDL & \\
\cline { 2 - 6 } & kidl & $0.13 \pm 0.06 \mathrm{a}$ & $0.10 \pm 0.04 \mathrm{a}$ & $0.11 \pm 0.03 \mathrm{a}$ & $>0.05$ \\
\hline
\end{tabular}

Means value along the same row with same superscript are not significantly different at $\mathrm{p}<0.05$

BDL: Below detection limit

Table 5. Grand Mean \pm standard deviation of Heavy metal concentrations in different tissues of (Chrysichthys nigrodigitatus) fish species from Badagry Creek (November, 2011 September, 2013)

\begin{tabular}{|c|c|c|}
\hline Metals & Fish tissues & Mean \pm SD \\
\hline \multirow[t]{4}{*}{$\mathrm{Fe}(\mathrm{mg} / \mathrm{kg})$} & Muscle & $45.74 \pm 20.89$ \\
\hline & Liver & $174.51 \pm 56.58$ \\
\hline & Gill & $206.23 \pm 21.79$ \\
\hline & Kidney & $66.66 \pm 11.94$ \\
\hline \multirow[t]{4}{*}{$\mathrm{Cu}(\mathrm{mg} / \mathrm{kg})$} & Muscle & $0.67 \pm 0.29$ \\
\hline & Liver & $2.77 \pm 1.32$ \\
\hline & Gill & $1.64 \pm 0.92$ \\
\hline & Kidney & $0.85 \pm 0.74$ \\
\hline \multirow[t]{4}{*}{$\mathrm{Pb}(\mathrm{mg} / \mathrm{kg})$} & Muscle & $15.11 \pm 2.01$ \\
\hline & Liver & $15.10 \pm 2.64$ \\
\hline & Gill & $18.06 \pm 2.70$ \\
\hline & Kidney & $14.86 \pm 3.36$ \\
\hline \multirow[t]{4}{*}{$\mathrm{Zn}(\mathrm{mg} / \mathrm{kg})$} & Muscle & $15.92 \pm 2.82$ \\
\hline & Liver & $13.80 \pm 2.84$ \\
\hline & Gill & $28.14 \pm 3.61$ \\
\hline & Kidney & $9.18 \pm 1.52$ \\
\hline \multirow[t]{4}{*}{$\mathrm{Cr}(\mathrm{mg} / \mathrm{kg})$} & Muscle & $94.30 \pm 25.84$ \\
\hline & Liver & $103.29 \pm 30.81$ \\
\hline & Gill & $115.61 \pm 29.47$ \\
\hline & Kidney & $86.30 \pm 22.15$ \\
\hline \multirow[t]{4}{*}{$\mathrm{Cd}(\mathrm{mg} / \mathrm{kg})$} & Muscle & BDL \\
\hline & Liver & BDL \\
\hline & Gill & $0.11 \pm 0.04$ \\
\hline & Kidney & $0.11 \pm 0.07$ \\
\hline
\end{tabular}

BDL: Below detection limit 


\section{Mll Macrothink}

Journal of Biology and Life Science

ISSN 2157-6076

2015, Vol. 6, No. 2

Table 6. Seasonal variation (Mean \pm standard deviation) of Heavy metal concentrations in different tissues of (Chrysichthys nigrodigitatus) fish species from Badagry Creek (November, 2011 - September, 2013).

\begin{tabular}{|c|c|c|c|c|}
\hline Metals & Fish tissues & Dry season & Wet season & $P$ value \\
\hline \multirow[t]{4}{*}{$\mathrm{Fe}(\mathrm{mg} / \mathrm{kg})$} & muscle & $43.43 \pm 23.88$ & $48.05 \pm 19.41$ & $>0.05$ \\
\hline & liver & $171.67 \pm 68.22$ & $177.35 \pm 48.67$ & $>0.05$ \\
\hline & gill & $207.26 \pm 68.70$ & $205.21 \pm 37.92$ & $>0.05$ \\
\hline & kidney & $66.90 \pm 14.32$ & $66.42 \pm 10.41$ & $>0.05$ \\
\hline \multirow[t]{4}{*}{$\mathrm{Cu}(\mathrm{mg} / \mathrm{kg})$} & muscle & $0.57 \pm 0.09$ & $0.46 \pm 0.13$ & $>0.05$ \\
\hline & liver & $3.93 \pm 0.71$ & $1.32 \pm 0.28$ & $>0.05$ \\
\hline & gill & $1.96 \pm 1.15$ & $0.97 \pm 0.28$ & $<0.05$ \\
\hline & kidney & $0.43 \pm 0.22$ & $0.70 \pm 0.68$ & $>0.05$ \\
\hline \multirow[t]{4}{*}{$\mathrm{Pb}(\mathrm{mg} / \mathrm{kg})$} & muscle & $14.51 \pm 1.85$ & $15.72 \pm 2.14$ & $>0.05$ \\
\hline & liver & $14.84 \pm 2.72$ & $15.36 \pm 2.79$ & $>0.05$ \\
\hline & gill & $18.32 \pm 2.25$ & $17.80 \pm 3.29$ & $>0.05$ \\
\hline & kidney & $12.76 \pm 2.86$ & $16.96 \pm 2.45$ & $<0.05$ \\
\hline \multirow[t]{4}{*}{$\mathrm{Zn}(\mathrm{mg} / \mathrm{kg})$} & muscle & $15.93 \pm 3.58$ & $15.91 \pm 2.17$ & $>0.05$ \\
\hline & liver & $12.72 \pm 2.93$ & $14.88 \pm 2.52$ & $>0.05$ \\
\hline & gill & $28.50 \pm 3.99$ & $27.78 \pm 3.52$ & $>0.05$ \\
\hline & kidney & $8.59 \pm 1.33$ & $9.77 \pm 1.57$ & $>0.05$ \\
\hline \multirow[t]{4}{*}{$\mathrm{Cr}(\mathrm{mg} / \mathrm{kg})$} & muscle & $115.18 \pm 18.44$ & $73.43 \pm 9.10$ & $<0.05$ \\
\hline & liver & $125.51 \pm 23.96$ & $81.07 \pm 18.14$ & $<0.05$ \\
\hline & gill & $140.39 \pm 17.43$ & $90.82 \pm 11.49$ & $<0.05$ \\
\hline & kidney & $104.92 \pm 11.07$ & $67.67 \pm 11.16$ & $<0.05$ \\
\hline \multirow[t]{4}{*}{$\mathrm{Cd}(\mathrm{mg} / \mathrm{kg})$} & muscle & $\mathrm{BDL}$ & $\mathrm{BDL}$ & \\
\hline & liver & $\mathrm{BDL}$ & $\mathrm{BDL}$ & \\
\hline & gill & $0.09 \pm 0.03$ & $0.12 \pm 0.02$ & $>0.05$ \\
\hline & kidney & $0.10 \pm 0.03$ & $0.13 \pm 0.00$ & $>0.05$ \\
\hline
\end{tabular}

BDL: Below detection limit

\section{Discussion}

The relatively higher metals concentration in fish tissues as compared to water in this study was in agreement with opinion of Chale, (2002) that concentrations of trace metals in fish tissues were always higher than that of water. Generally, heavy metals exist in low levels in water and attained considerable concentration in sediments and biota (Naminga and Wilhm, 1976). 


\section{Macrothink}

The mean concentrations of metals $(\mathrm{Fe}, \mathrm{Cu}, \mathrm{Zn}, \mathrm{Cr}$ and $\mathrm{Cd}$ ) in water and finfish from Badagry creek in this study though slightly lower, compared favourably with previous studies (Okoye, 1989; Oyewo 1998; Don-Pedro et al., 2004 and Adeniyi and Yusuf, 2007) in the Lagos lagoon complex and adjoining water bodies. However, $\mathrm{Pb}$ concentrations in water and finfish in the present study were higher than the Nigeria coastal waters background levels and permissible limits. The high $\mathrm{Pb}$ concentration in water and finfish observed in this study may be attributed to increasing automobile traffic emissions from lead tetraethyl in gasoline and emissions from heavy duty electric generators used in the industry to the environment. $\mathrm{Pb}$ is a great threat to life if present in substantial quantity because it is toxic even at low concentrations and has no known function in biochemical processes (Burden et al., 1998). The probable sources of $\mathrm{Cd}$ in surface water as recorded in this study may be attributed to leaching from $\mathrm{Ni}$ - Cd batteries, run off from agricultural soils where phosphate fertilizers are used and other wastes (Pate et al., 2001).

The relatively lower wet season $\mathrm{Cu}, \mathrm{Pb}, \mathrm{Cr}$ and $\mathrm{Cd}$ in water could be attributed to a dilution effect of rainfall. Although, presently the mean concentrations of all the heavy metals except $\mathrm{Pb}$ in this study were moderate and within the permissible standard limit of FEPA, (1991), the elevation of metal concentrations in the creek is inevitable under the prevailing conditions of increasing urbanization in Badagry and environs. In comparison among metals studied in this creek water, $\mathrm{Cr}$ concentrations were highest in the water samples. Similar finding was reported in Awassa and Koka Rift Valley Lakes, Ethiopia (Dsikowitzky et al., 2012).

Fish attracted a lot of attention as bio indicators for monitoring aquatic pollution, due to their relatively large body size, long life cycle, position in the aquatic food chain and their use for human consumption (Zhou et al. 2008). The fish investigated for heavy metals in the present study Cat Fish (Chrysichthys nigrodigitatus) is a commercially exploited species and occur frequently in Nigeria coastal waters. Accordingly, a couple of studies about heavy metal levels in different tissues of this fish species were published (Oyewo, 1998; Asuquo et al., 2004; Ladigbolu et al., 2011 and Opaluwa et al., 2012).

The high value of Fe observed in $C$. nigrodigitatus in this study compared to other metals may be due to increase in total dissolved iron in the creek. The values of Fe in the fish organs were in the order: Gill > Liver > Kidney > Muscle. High concentration of Fe had been reported in fish organs (El-Naggar et al., 2009) and was reported as the most abundant in $C$. nigrodigitatus compared to other fishes evaluated (Asuquo et al., 2004). However, the concentrations obtained for Fe in this study were higher compared to values reported for this fish in Ibeshe, Lagos lagoon (Ladigbolu et al., 2011).

All the metals investigated in the fish species except $\mathrm{Cu}$ (highest concentration in the liver) had highest concentrations in the gills part. This observation may be attributed to the fact that the gills helps in respiration and filtration of water. Kebede and Wondimu (2004) reported higher $\mathrm{Pb}$ concentrations in the gills compared with the muscles in O. niloticus from Lake Awassa and Lake Ziway. In fish, gills are considered to be the dominant site for contaminant uptake because of their anatomical and/or physiological properties that maximize absorption efficiency from water. In the present study, $\mathrm{Cr}$ contents were generally higher in the gills and 
livers than in the muscles. This observation agrees with those of Amundsen et al., (1997) freshwater fish species from the border region between Norway and Russia.

\section{Conclusion}

This study has established the current levels of some metals in water and Cat fish (Chrysichthys nigrodigitatus) in Badagry Creek ecosystem. Based on information gathered, all investigated metals except $\mathrm{Pb}$ were within the permissible standard limit for aquatic life. The implication is that $\mathrm{Pb}$ is posing an environmental risk in this water body and calls for in-depth monitoring.

\section{Acknowledgement}

The authors convey their huge indebtedness to Dr. E. O Ajao, the Acting Executive Director of Nigerian Institute for Oceanography and Marine Research for allowing the use of the institute central laboratory for this work at no cost and to the Head and staff of NIOMR central laboratory for their assistance.

\section{References}

Adeniyi, A. A, \& Yusuf, K. A. (2007). Determination of heavy metals in fish tissues, water and bottom sediments from Epe and Badagry Lagoons, Lagos, Nigeria. Environmental Monitoring and Assessment, 37, 451 - 458.

Adepoju-Bello AA, and Alabi OM (2005). Heavy metals: A review. The Nig J Pharm. 37: 41-45.

Agboola J. I, Anetekhai M. A, \& Denloye A. B (2008). Aspects of the ecology and fishes of Badagry creek Nig. Journal of fisheries and aquatic science. 3(3), 184-194. http://dx.doi.org/10.3923/jfas.2008.184.194

Amundsen, P.-A., Staldvik, F. J., Lukin, A. A., Kashulin, N. A., Popova, O. A., \& Reshetnikov, Y. S. (1997). Heavy metal contamination in freshwater fish from the border region between Norway and Russia.The Science of the Total Environment, 201, 211-224. http://dx.doi.org/10.1016/S0048-9697(97)84058-2

Akan JC, Abdurrahman FI, Sodipo OA, Ochanya AE, \& Askira YK (2010). Heavy metals in sediments from River Ngada, Maiduguri Metropolis, Borno State,Nigeria. J Environ Chem Eco Toxicol 2,131-140.

Anyanwu, A. J., \& Ezenwa, B. I. O. (1988). Incidence of parasitic infection of pond raised Tilapia spp. and some cultivable fish species from three ecological areas of Lagos state. Nigeria Institute of Oceanography and Marine Research, Technical Paper No. 32.

American Public Health Association (APHA), (1998). Standard methods for the examination of water and wastewater, 20th ed. Clesceri LS, Greenberg AE, \& Eaton, AD, (Eds); American Public Health Association: Washington, DC.

Asuquo FE, Ewa-Oboho I, Asuquo EF, Udo PJ (2004). Fish Species Used as Biomarker for Heavy Metal and Hydrocarbon Contamination for Cross River, Nigeria. Environmentalist. 24, 
29-37. http://dx.doi.org/10.1023/B:ENVR.0000046344.04734.39

Bhattacharya, B., Sarkar, S. K., \& Maji, P. K. (1994). Bioaccumulation of heavy metals in flora and fauna of Hooglily Estuary, East coast of India. Toxicol. Environ. Chem., 42, 123-130. http://dx.doi.org/10.1080/02772249409357994

Burden VM, Sandheinrich MB, Caldwell CA (1998). Effects of lead on the growth and alpha aminolevulinic acid dehydrates activity of juvenile rainbow trout, Oncorhynchus mykiss. Environ. Poll. 101, 285-289. http://dx.doi.org/10.1016/S0269-7491(98)00029-3

Chale, F. M. (2002). Trace metal concentration in water,sediments and fish tissues from lake. Tanganyika. Science of Total Environment, 299, 155-161. http://dx.doi.org/10.1016/S0048-9697(02)00252-8

Don Pedro K, N. Oyewo E. O., \& Otitoloju A. A (2004). Trend of Heavy metal concentrations in Lagos Lagoon Ecosystem, Nigeria, W/A Jour. of Applied Ecology 5, pp 103-114.

Dsikowitzky L, Mengesha M, Dadebo E, Veiga de Carvalho C. E., \& Sindern S. (2012). Assessment of heavy metals in water samples and tissues of edible fish species from Awassa and Koka Rift Valley Lakes, Ethiopia Environ Monit Assess. http://dx.doi.org/10.1007/s10661-012-2777-8.x

El-Naggar AM, Mahmoud SA, Tayel SI (2009). Bioaccumulation of Some Heavy Metals and Histopathological Alterations in Liver of Oreochromis niloticus in Relation to Water Quality at Different Localities along the River Nile, Egypt. World J. Fish Mar. Sci. 1(2), 105-114

Federal Environmental Protection Agency (1991) Guidelines and Standards for Environmental Pollution Control in Nigeria.

ISO, 2006 ISO Standard 5667 - 1: 2006 / Water quality — sampling - Part 1: Guidance on the design of sampling programmes and sampling techniques. Geneva

Kebede, A., and Wondimu, T. (2004). Distribution of trace elements in muscle and organs of Tilapia, Oreochromis niloticus, from lakes Awassa and Ziway, Ethiopia. Bulletin of the Chemical Society of Ethiopia, 18, 119-130. http://dx.doi.org/10.4314/bcse.v18i2.61427

Ladigbolu I A, Balogun K. J and Shelle R.O (2011). Hydrochemistry and levels of some heavy metals in samples of Ibeshe, Lagos Lagoon Complex, Nigeria. Journal of American Science 2011, 7(1), 625-632.

Namminga, H.N and Wilhm, J. (1976). Effect of high discharge and an oil refinery cleanup operation on heavy metals in water and sediments in skeleton creek. Proceedings of the Oklahoma Academy of Science, 56, 133-138.

Okoye B. C (1989). A study of some Heavy metals in Lagos Lagoon. PhD Thesis O.A.U Ile Ife, Nigeria, 142pp.

Opaluwa O. D, Aremu M. O, Ogbo O. L, Magaji J. I, Odiba I. E., \& Ekpo E. R, (2012). Assessment Of Heavy Metals In Water, Fish And Sediments From UKE Stream, Nasarawa 


\section{Macrothink}

State, Nigeria Curr. World Environ., 7(2), 213-220. http://dx.doi.org/10.12944/CWE.7.2.04

Oyewo EO (1998). Industrial Sources and Distribution of Heavy Metals in Lagos Lagoon and Biological Effect on Estuarine Animals. Ph.D Thesis. University of Ibadan p. 279

Pate K. P. Pandy R. M., \& George L. (2001). Heavy metal content of different effluents water around major industrial cities of Guryurat, J. of Indian Society of Soil Sci., 59(1), 89-94 (2001).

Zhou, Q., Zhang, J., Fu, J., Shi, J., Jiang, G. (2008). Biomonitoring: An appealing tool for assessment of metal pollution in the aquatic ecosystem. Analytica Chimica Acta 606, 135-150. http://dx.doi.org/10.1016/j.aca.2007.11.018

\section{Copyright Disclaimer}

Copyright for this article is retained by the author(s), with first publication rights granted to the journal.

This is an open-access article distributed under the terms and conditions of the Creative Commons Attribution license (http://creativecommons.org/licenses/by/3.0/). 